\title{
Methodology for pattern determination in electroencephalographic signals
}

\section{Metodología para la determinación de patrones en señales electroencefalográficas}

\author{
ESQUEDA-ELIZONDO, José Jaime †*, TRUJILLO-TOLEDO, Diego Armando, PINTO-RAMOS, \\ Marco Antonio and REYES-MARTÍNEZ, Roberto Alejandro
}

Universidad Autónoma de Baja California, Facultad de Ciencias Químicas e Ingeniería

ID $1^{\text {st }}$ Author: José Jaime, Esqueda-Elizondo / ORC ID: 0000-0001-8710-8978, CVU CONACYT ID: 90966

ID $1^{\text {st }}$ Coauthor: Diego Armando, Trujillo-Toledo / ORC ID: 0000-0003-1482-8581, CVU CONACYT ID: 232755

ID $2^{\text {nd }}$ Coauthor: Marco Antonio, Pinto-Ramos / ORC ID: 0000-0003-4748-6012, CVU CONACYT ID: 1790582

ID $3^{\text {rd }}$ Coauthor: Roberto Alejandro, Reyes-Martínez / ORC ID: 0000-0003-2210-2692, CVU CONACYT ID: 214730

DOI: $10.35429 / J R D .2019 .16 .5 .21 .27$

Received October 17, 2019; Accepted December 03, 2019

\begin{abstract}
A methodology for the selection and determination of electroencephalographic (EEG) signal patterns is presented at the case study level, which can later be used as on-off control signals in other applications. Electroencephalographic signals are acquired through the use of a brain-computer interface (BCI). These systems capture electrical signals from the cortex of the brain and transfer them to a computer so that they can be analyzed by algorithms and some action is taken. In this case, the EEG signals are acquired through the wireless 14-channel Epoc+ platform. The methodology used consists first in acquiring signals from the user sample in three scenarios: in relaxation, thinking about turning on and off. Subsequently, the wavelet transform of each of the channels is obtained for each of the cases and the most significant coefficients are taken into account. Then, through digital signal processing algorithms, descriptive parameters are obtained for the on and off cases, which are used as patterns to describe each of the actions. With this information, a comparison between the incoming signals and the previously stored patterns is made to execute one of the established commands.
\end{abstract}

Patterns, EEG, Case of study

\begin{abstract}
Resumen
Se presenta como caso de estudio, una metodología para la selección y determinación de patrones de señales electroencefalográficas (EEG), que pueden ser empleados como señales de control encendido-apagado en otras aplicaciones. Las señales electroencefalográficas se adquieren mediante el uso de una interfaz cerebro computadora (Brain Computer Interface, BCI). Estos sistemas capturan las señales eléctricas de la corteza del cerebro y las transfieren a una computadora, para que se puedan analizar mediante algoritmos y se toma alguna acción. En este caso se adquieren las señales EEG mediante la plataforma de 14 canales Epoc+. La metodología empleada consiste primero en adquirir señales de la muestra de usuarios en tres escenarios: en relajación, pensando en encender y en apagar. Posteriormente, se obtiene la transformada wavelet de cada uno de los canales para cada uno de los casos y se toman en cuenta los coeficientes más significativos. A continuación, mediante algoritmos de procesamiento digital de señales se obtienen parámetros descriptivos para los casos de encender y apagar, los cuales se utilizan como patrones para describir cada una de las acciones. Con esta información se hace una comparación entre las señales entrantes y los patrones previamente almacenados para ejecutar uno de los comandos establecidos.
\end{abstract}

Patrones, EEG, Caso de estudio

Citation: ESQUEDA-ELIZONDO, José Jaime, TRUJILLO-TOLEDO, Diego Armando, PINTO-RAMOS, Marco Antonio and REYES-MARTÍNEZ, Roberto Alejandro. Methodology for pattern determination in electroencephalographic signals. Journal of Research and Development. 2019 5-16: 21-27

\footnotetext{
* Correspondence to Author (Email: jjesqueda@uabc.edu.mx)

$\dagger$ Researcher contributing as first author.
} 


\section{Introduction}

In late years, there have been developed some brain-computer interfaces (BCI) that acquire the electrical signal from the brain cortex. With this BCI Systems is possible to interact with some devices through the processing of the electroencephalographic signals. These systems include the hardware and software needed to acquire and communicate the EEG signals with a computer or microprocessor (Ramadan \& Vasilakos, 2017a).

The measurement of the electrical activity of the brain is called electroencephalogram (EEG) and is taken by electrodes placed on the scalp of the subject. These electrodes measure the electrical activity of the brain cortex and are placed using a standardized scheme (Al-Fahoum \& Al-Fraihat, 2014).

With digital signal processing algorithms is possible to extract features that can describe some thinking patterns and that can be used to control some devices (Al-Fahoum \& Al-Fraihat, 2014). The quality of the patterns is defined by the feature extractions techniques used. There are many kinds of techniques that are widely used nowadays.

Feature extraction allows extracting more useful or descriptive information hidden in a signal by reducing unnecessary or redundant information. Using digital signal processing algorithms is possible to reduce noise, interference, and artifacts before the feature extraction process begins. Once the feature extraction is done, the classification process can be done (W Azlan \& Low, 2014) (Krishnan \& Athavale, 2018).

In this paper, we show a methodology, applied to two datasets, that can be used for determining useful patterns for controlling systems applications.

We show how we use coherence and entropy as the base in order to determine these patterns. We also comment on some of our experiences in this experiment.

The intention of this paper is to give a kind of guideline to pattern election for beginners.

\section{Methodology}

There are some EEG platforms available, like Open BCI, Epoc+, Neurosky, among others. In this case, The EEG signals, are taken with the Epoc+ via the Emotiv Pro software, which is supplied by the Emotiv company (Ramadan \& Vasilakos, 2017b)(Esqueda Elizondo, José Jaime, Rosique Ramírez, Súa Madaí, Pinto Ramos, Marco Antonio, Trujillo Toledo, 2018) (Esqueda Elizondo, José Jaime, Chávez Guzmán, Carlos Alberto, Jiménez Beristáin, Laura, Bermúdez Encarnación, 2018). This software communicates the headset with the PC and saves the EEG signal in a .edf format or it can convert it to a .csv format, so it can be used in other platforms like (in this case) Matlab.

\section{Test Signals}

Three EEG one-minute signal register of two people of 22 and 24 years (A and B), thinking first in neutral or relax, then in right and finally in left was taken. The signals were recorded seated with their eyes open, one register at the time. This data set was used in (Esqueda Elizondo José Jaime, Hernández Manzo Diana, Bermúdez Encarnación Enrique, Jimenez Beristáin Laura, 2016).

\section{Signal Preprocessing}

First, the signal is filtered with a $5^{\text {th }}$ order sync digital filter and also with notch filters at $50 \mathrm{~Hz}$ and $60 \mathrm{~Hz}$. These filters are built in the Epoc+ headset. After that, we remove the mean for each channel in order to eliminate de isoelectric line for all the channels. Then the value obtained is multiplied by $0.51 \mu \mathrm{V}$, that corresponds to the Analog do Digital Converter resolution, in order to convert the signal to volts. This procedure is shown in figure 1 .

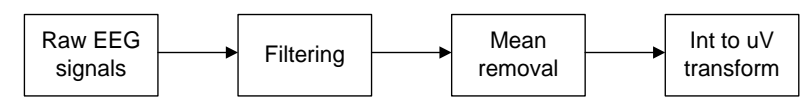

Figure 1 Signal preprocessing. Source: self-made.

\section{Entropy}

Entropy is a computational complexity sensitive tool that assesses the signal dynamics in a time series data. Neural systems are neither completely a random process nor a completely regular one, the measurements of the complexity should have low values for a completely random or a completely regular system (David et al., 2016). 
Entropy can be used as a simple nonlinear feature extraction technique. In this paper Shannon, Log Energy and Normalized Entropies are used.

\section{Coherence}

Coherence is a frequency function, presented in normalized units, that indicates how much the power spectral density of one signal $x(t)$, corresponds to the other one $y(t)$. Coherence is a quadratic correlation coefficient that estimates the consistency of the amplitude and phase related between two signals in a frequency band. When the coherence value is 1 , this means that the signal $x(t)$ totally corresponds to signal $y(t)$, and they are the same signal. Coherence is given by the equation:

$\Gamma^{2}(f)=\frac{\left|S_{x y}(f)\right|^{2}}{S_{x x}(f) S_{y y}(f)} ; \quad 0 \leq \Gamma(f) \leq 1$.

Where $\operatorname{Sxy}(f)$ is the crossed Power Spectrum Density of signals $x(t)$ and $y(t), S x x(f)$ is the self-Spectrum of the signal $x(t)$ and $\operatorname{Syy}(f)$ is the self-Spectrum of the signal $y(t)$. Any pair of signals can be coherent in some frequency bands and not in another one. In contrast with the amplitude measurements, coherence measures the synchronization between two signals based principally on the phase consistency. This represents that if two signals have different phase (as in the common linear simple circuits). A high coherence value (near to 1) is presented when the phase difference tends to stay constant. For each frequency, the cohere measures when the signals are related one to each other with a linear and time-invariant transformation (Srinivasan, Winter, Ding, \& Nunez, 2007).

\section{Feature extraction}

Once the signal is preprocessed, the feature extraction stage can be done. For the feature extraction Entropy, Coherence and the entropies of the Discrete Wavelet Transform are used. First, a visual inspection is made for identifying some possible patterns.

Then, some segments of the signal containing those possible patterns are taken and then the Entropy and Coherence functions are obtained in order to verify that they have similar levels. This is indicative that they have similarities.
Then, a four-level Discrete Wavelet Decomposition is done in order to obtain the detailed coefficients (Dx) and the approximated coefficients $(\mathrm{Ax})$. Next, the Entropy of the coefficients Dx and Ax are obtained, according to the scheme presented by (Djemal, Alsharabi, Ibrahim, \& Alsuwailem, 2017) and shown in figure 2 .

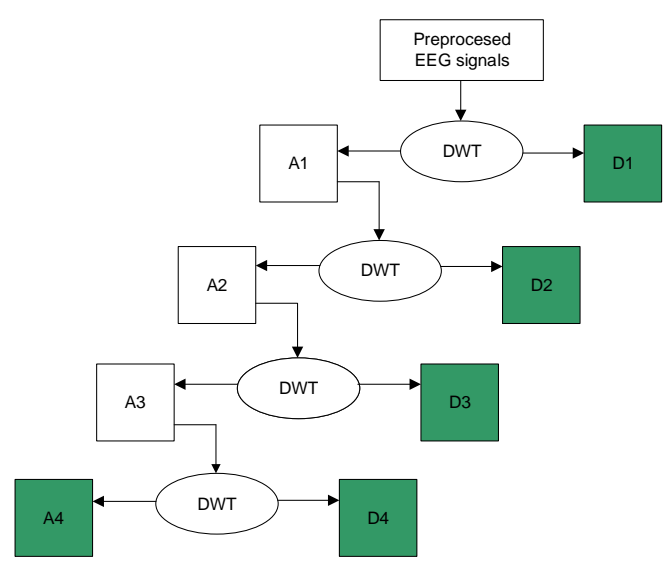

Figure 2 4-level Discrete Wavelet Transform decomposition. Source: (Djemal et al., 2017)

\section{Selecting possible patterns}

In this case of study, the analysis begins with the preprocessing of the EEG signals shown in Figure 1. First, an entropy analysis is done in order to detect similar entropy values using a 128 samples window, that is equivalent to one second. Whit this analysis we detect EEG data segments that have similar entropy values. Figure 3 shows the Shannon entropy analysis for a one-second window of an EEG signal. This signal corresponds to the electrode $\mathrm{O} 1 \mathrm{of}$ the left test. Then we take these segments of these particular electrodes or channels and the coherence is obtained. Next, the Shannon, Log Energy and Normalized Entropies of the pair of analyzed segments are obtained in order to verify their relationship. This process is shown in figure 3.

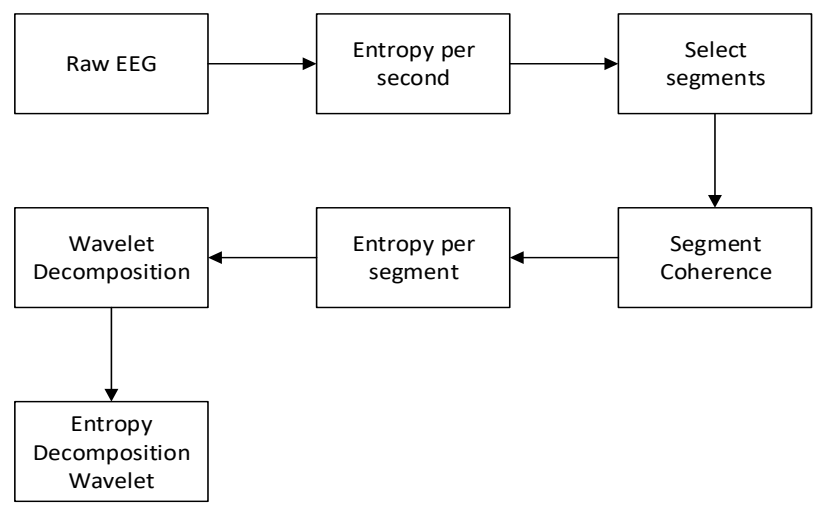

Figure 3 Block diagram of the process Source: Self-Made

ESQUEDA-ELIZONDO, José Jaime, TRUJILLO-TOLEDO, Diego Armando, PINTO-RAMOS, Marco Antonio and REYES-MARTÍNEZ, Roberto Alejandro. Methodology for pattern determination in electroencephalographic signals. Journal of Research and Development. 2019 


\section{Experiments in user $\mathrm{A}$}

First, the dataset of user A was preprocessed and then the one-second entropies were obtained for all the one-minute test.

Figure 4 shows similar Shannon entropies obtained in an EEG signal. The similar values are circled in colors.

Table 1 and 2 show the Shannon, Log Energy, and Normalized Entropies obtained with the two one second segments of the electrodes AF3 and $\mathrm{O} 1$ of the subject D, obtained during the left test and $\mathrm{O} 2$ and $\mathrm{T} 8$ during the right test, respectively. We can notice that are similar values are obtained.

Figure 5 and Figure 6 show the coherence of a pair of these two segments. We observe that they have high coherence in almost all the signal bandwidth. All of the signal processing was done in Matlab Version 9.0.0.341360 (R2016a).

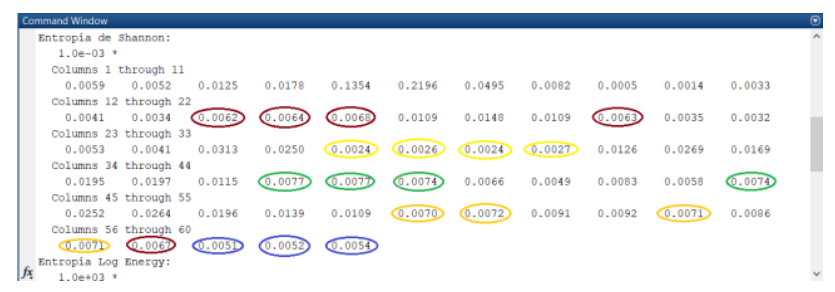

Figure 4 Similar Shannon entropies detected in an EEG signal

Source: Self-Made

\begin{tabular}{|c|c|c|c|}
\hline $\begin{array}{l}\text { Channel } \\
\text { Time }\end{array}$ & $\begin{array}{c}\text { Entropy } \\
\text { (Shannon) }\end{array}$ & $\begin{array}{c}\text { Entropy } \\
\text { (Log Energy) }\end{array}$ & $\begin{array}{l}\text { Entropy } \\
\text { (Norm) }\end{array}$ \\
\hline $\begin{array}{r}\text { AF3 } \\
\text { 8s \& 33s }\end{array}$ & $\begin{array}{l}6.0682 \mathrm{e}-05 \\
5.9660 \mathrm{e}-05\end{array}$ & $\begin{array}{l}-2.2483 e+03 \\
-2.2509 e+03\end{array}$ & $\begin{array}{l}0.0089 \\
0.0088\end{array}$ \\
\hline $\begin{array}{r}O 1 \\
14 \mathrm{~s} \& 15 \mathrm{~s}\end{array}$ & $\begin{array}{l}0.0062 \mathrm{e}-4 \\
0.0064 \mathrm{e}-4\end{array}$ & $\begin{array}{l}-2.5391 \\
-2.5344\end{array}$ & $\begin{array}{l}0.0023 \\
0.0024\end{array}$ \\
\hline
\end{tabular}

Table 1 Subject A, left test and entropy values Source: Self-Made

\begin{tabular}{|r|c|r|r|}
\hline Channel & $\begin{array}{c}\text { Entropy } \\
\text { (Shannon) }\end{array}$ & $\begin{array}{c}\text { Entropy } \\
\text { (Log Energy) }\end{array}$ & $\begin{array}{c}\text { Entropy } \\
\text { (Norm) }\end{array}$ \\
\hline F4 & $0.2732 \mathrm{e}-03$ & $-2.0248 \mathrm{e}+03$ & 0.00213 \\
$8 \mathrm{~s} \& 23 \mathrm{~s}$ & $0.2717 \mathrm{e}-03$ & $-2.0255 \mathrm{e}+03$ & 0.0213 \\
\hline $\mathrm{T} 8$ & $5.7666 \mathrm{e}-05$ & $-2.2552 \mathrm{e}+03$ & 0.0086 \\
$18 \mathrm{~s} \& 21 \mathrm{~s}$ & $5.1997 \mathrm{e}-05$ & $-2.2694 \mathrm{e}+03$ & 0.0081 \\
\hline
\end{tabular}

Table 2 Subject A, right test and entropy values Source: Self-Made

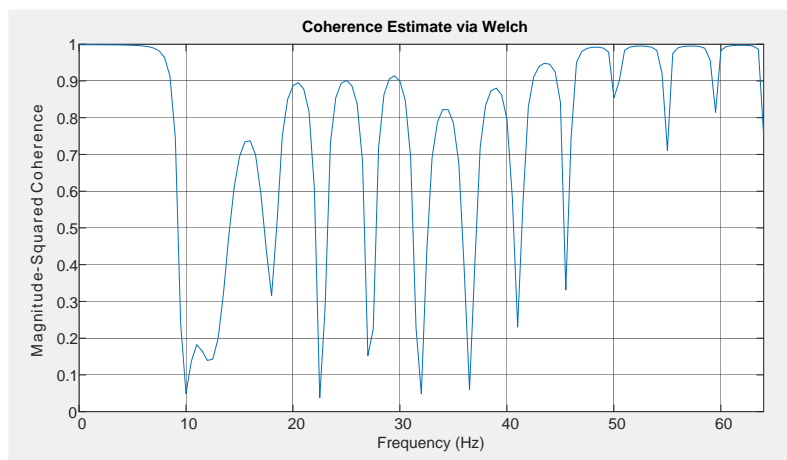

Figure 5 The coherence of two segments of channel AF3, Subject A, left test Source: Self-Made

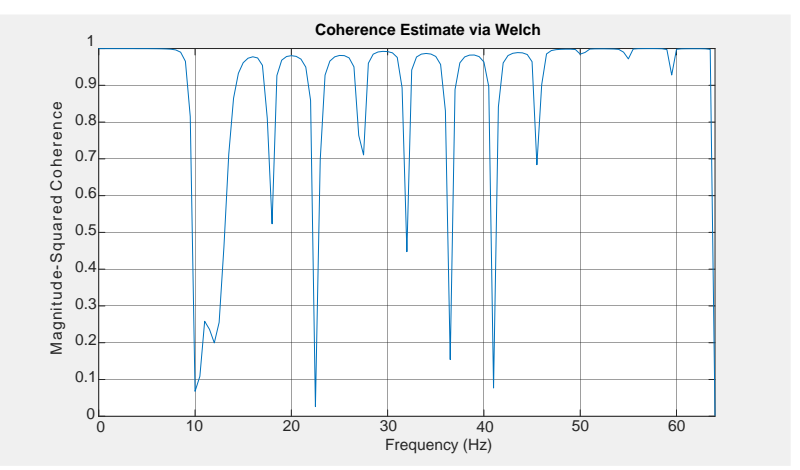

Figure 6 The coherence of two segments of channel F4, Subject A, right test Source: Self-Made

Then, if the estimated coherence is acceptable, the four-level Wavelet decomposition of each segment can be obtained, as it is shown in Figure 2. Once the wavelet decomposition is obtained, the Shannon, Log Energy and Normalized Entropies of the detailed coefficients dA3, dA4 and the approximation coefficient A4 are calculated. Tables 3, 4 and 5 show the Shannon, Log Energy and Normalized entropies calculated from the Discrete Wavelet Decomposition, obtained for the same electrodes and segments as in Tables 1 and 2. With this information, the entropy of the segments, coherence and the entropy of the DWT coefficients, the consistency of the pattern can be validated, if the entropy values obtained are similar.

In Table 3 we observe that the Shannon entropies are different, but Log Energy and Normalized entropies for the Detail coefficients are closer.

In Table 4, we observe again that Shannon and Normalized entropies are quite different, but the Log Energy ones are similar. 


\begin{tabular}{|c|c|c|c|}
\hline $\begin{array}{c}\text { Electrode } \\
\text { AF3 }\end{array}$ & Shannon & Log Energy & Norm \\
\hline 8 sec. & $5.8756 \mathrm{e}-09$ & -430.9594 & $1.2347 \mathrm{e}-05$ \\
\hline 33 sec. & $1.3581 \mathrm{e}-08$ & -398.1880 & $2.4502 \mathrm{e}-05$ \\
\hline
\end{tabular}

Table 3 Subject A, entropies for detail coefficient A3 for the left test

Source: Self-Made

\begin{tabular}{|r|r|r|c|}
\hline \multicolumn{1}{|c|}{ Electrode } & \multicolumn{3}{|c|}{ D4 (Entropy) } \\
AF3 & \multicolumn{1}{|c|}{ Shannon } & Log Energy & Norm \\
\hline 8 sec. & $2.6990 \mathrm{e}-09$ & -204.8071 & $7.3692 \mathrm{e}-06$ \\
\hline 33 sec. & $8.9709 \mathrm{e}-09$ & -198.3364 & $1.4654 \mathrm{e}-05$ \\
\hline
\end{tabular}

Table 4 Subject A, entropies for detail coefficient A4 for the left test.

Source: Self-Made

Table 5 shows the entropies calculated for the approximation coefficients A4 for the AF3 electrode in the left test. We observe that all the entropies are similar and these entropies are different from the ones obtained using only the one-second data segments.

\begin{tabular}{|r|r|r|r|}
\multicolumn{1}{c}{ Electrode } & \multicolumn{3}{c|}{ A4 (Entropy) } \\
AF3 & Shannon & Log Energy & \multicolumn{1}{l|}{ Norm } \\
\hline 8 sec. & $5.6674 \mathrm{e}-05$ & -131.9524 & 0.0028 \\
\hline 33 sec. & $5.6309 \mathrm{e}-05$ & -132.0304 & 0.0028 \\
\hline
\end{tabular}

Table 5 Subject A, entropies for approximation coefficient A4 for a left test

Source: Self-Made

\section{Experiments in user B}

In this section, the analysis for subject $\mathrm{B}$ is presented. Electrode P7 was chosen because it presented similar entropy values and coherence. Some of the entropies obtained for two segments are shown in Table 6. The coherence of this pair of segments is shown in figure 7. It is observed that is not a very good one, except for the band near $30 \mathrm{~Hz}$.

Table 7 shows the entropies of the detailed coefficients A3. It is observed that the values are not close enough, except for the Normalized, that are similar.

\begin{tabular}{|r|r|r|r|}
\hline \multicolumn{1}{|c}{$\begin{array}{c}\text { Channel } \\
\text { Time P7 }\end{array}$} & $\begin{array}{c}\text { Entropy } \\
\text { (Shannon) }\end{array}$ & \multicolumn{1}{c|}{$\begin{array}{c}\text { Entropy } \\
\text { (Log Energy) }\end{array}$} & \multicolumn{1}{c|}{$\begin{array}{c}\text { Entropy } \\
\text { (Norm) }\end{array}$} \\
\hline $23 \mathrm{~s}$ & $4.7741 \mathrm{e}-05$ & $-2.2812 \mathrm{e}+03$ & 0.0077 \\
\hline $52 \mathrm{~s}$ & $9.8571 \mathrm{e}-05$ & $-2.1871 \mathrm{e}+03$ & 0.0117 \\
\hline
\end{tabular}

Table 6 Entropies for subject B, right test Source: Self-Made

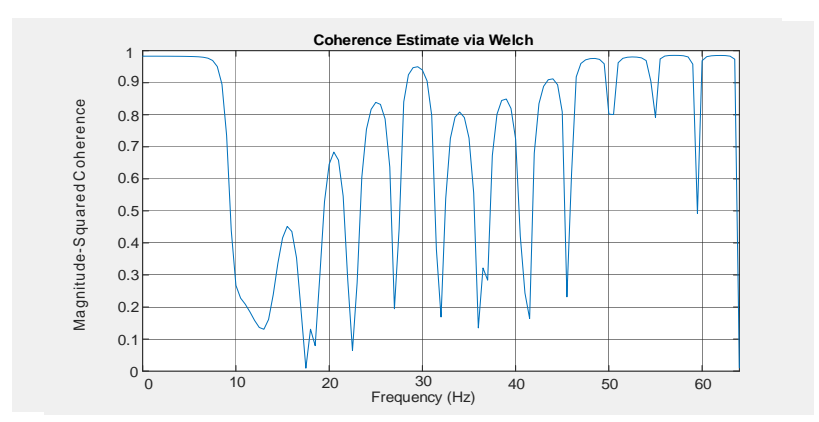

Figure 7 The coherence of two segments of electrode P7, Subject B, right test

Source: Self-Made

\begin{tabular}{c|r|r|c|} 
Electrode & \multicolumn{3}{c|}{ D3 (Entropy) } \\
P7 & Shannon & Log Energy & Norm \\
\hline 23 sec. & $1.4247 \mathrm{e}-08$ & -405.1969 & $2.3961 \mathrm{e}-05$ \\
\hline $52 \mathrm{sec}$. & $2.2473 \mathrm{e}-08$ & -386.3170 & $3.4070 \mathrm{e}-05$ \\
\hline
\end{tabular}

Table 7 Subject B, entropies for detail coefficient A3 for the right test

Source Self-Made

Table 8 presents the entropies for the detail coefficients A4 or the P7 electrode. None of them are close enough. Table 9 shows the entropies for the approximation coefficients for A4 and as in Table 8, the entropies are not similar.

\begin{tabular}{c|c|r|c|}
\hline Electrode & \multicolumn{3}{|c|}{ D4 (Entropy) } \\
P7 & \multicolumn{1}{|c|}{ Shannon } & Log Energy & Norm \\
\hline 23 sec. & $8.7090 \mathrm{e}-09$ & -200.0164 & $1.2708 \mathrm{e}-05$ \\
\hline 52 sec. & $5.0026 \mathrm{e}-08$ & -186.9553 & $3.8515 \mathrm{e}-05$ \\
\hline
\end{tabular}

Table 8 Subject B, entropies for detail coefficient A4 for the right test

Source: Self-Made

Table 9 shows the entropies for the Approximation coefficients A4 of the DWT of the P7 segments. It is noticed that the entropies obtained do not completely match each other. In this case, we can conclude that these segments are not trustworthy. It would be necessary to look for another electrode or segment, for the search of patterns.

ESQUEDA-ELIZONDO, José Jaime, TRUJILLO-TOLEDO, Diego Armando, PINTO-RAMOS, Marco Antonio and REYES-MARTÍNEZ, Roberto Alejandro. Methodology for pattern determination in electroencephalographic signals. Journal of Research and Development. 2019 
Table 10 shows the entropies of the segments obtained for the electrodes T8 and F3 for the left test of subject B. It is observed that almost all of them have similar values, except for Shannon entropy for T8. The coherence for the segments of both electrodes is presented in figures 8 and 9 . The coherence obtained is regular in both cases, in spite of the close entropy values shown in Table 10.

\begin{tabular}{|r|r|r|c|}
$\begin{array}{c}\text { Electrode } \\
\text { P7 }\end{array}$ & \multicolumn{3}{c|}{ A4 (Entropy) } \\
\hline & Shannon & Log Energy & Norm \\
\hline 23 sec. & $4.4841 \mathrm{e}-05$ & -134.2122 & 0.0025 \\
\hline 52 sec. & $9.5113 \mathrm{e}-05$ & -127.3002 & 0.0038 \\
\hline
\end{tabular}

Table 9 Subject B, entropies for approximation coefficient A4 for the right test Source: Self-Made

\begin{tabular}{|r|c|c|c|}
\multicolumn{1}{c}{$\begin{array}{c}\text { Electrode } \\
\text { Time }\end{array}$} & \multicolumn{1}{c}{$\begin{array}{c}\text { Entropy } \\
\text { (Shannon) }\end{array}$} & \multicolumn{1}{c|}{$\begin{array}{c}\text { Entropy } \\
\text { (Log Energy) }\end{array}$} & $\begin{array}{c}\text { Entropy } \\
\text { (Norm) }\end{array}$ \\
\hline T8 & $5.2676 \mathrm{e}-05$ & $-2.2680 \mathrm{e}+03$ & 0.0082 \\
$55 \mathrm{~s} \& 56 \mathrm{~s}$ & $5.4524 \mathrm{e}-05$ & $-2.2633 \mathrm{e}+03$ & 0.0083 \\
\hline F3 & $2.7070 \mathrm{e}-05$ & $-2.3600 \mathrm{e}+03$ & 0.0055 \\
$7 \mathrm{~s} \& 36 \mathrm{~s}$ & $2.7018 \mathrm{e}-05$ & $-2.3600 \mathrm{e}+03$ & 0.0055 \\
\hline
\end{tabular}

Table 10 Entropies Subject B for the left test, electrodes $\mathrm{T} 8$ and $\mathrm{F} 3$

Source: self-Made

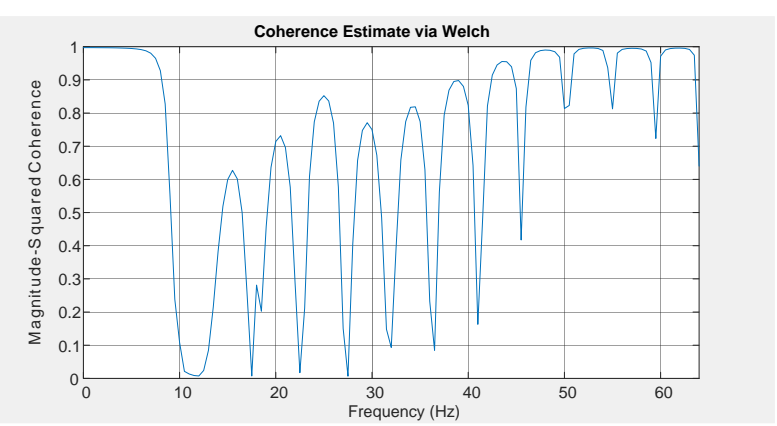

Figure 8 The coherence of two segments of channel T8, Subject B, left test Source: Self-Made

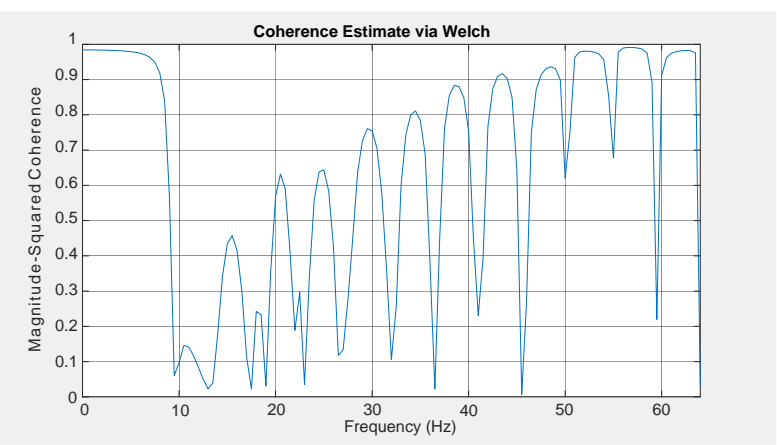

Figure 9 The coherence of two segments of channel F3, Subject B, left test Source: Self-Made
Table 11 shows the entropies for the detail coefficients D3 of the segments of electrode T8. Closer entropy values were obtained for the Log Energy and the Normalized entropies. Table 12 shows the entropies obtained for the Detail coefficients D4 for electrode T8. These entropies values are discrepant. The closer ones are Log Energy.

\begin{tabular}{c|c|c|c|} 
Electrode & \multicolumn{3}{c|}{ D3 (Entropy) } \\
T8 & Shannon & Log Energy & Norm \\
\hline $55 \mathrm{~s}$ & $7.4101 \mathrm{e}-09$ & -413.338 & $1.6802 \mathrm{e}-05$ \\
\hline $56 \mathrm{~s}$ & $5.1398 \mathrm{e}-09$ & -415.282 & $1.4026 \mathrm{e}-05$ \\
\hline
\end{tabular}

Table 11 Subject B, left test and entropy values for A3 detail Coefficients

Source: Self-Made

Table 13 shows the entropy values obtained for the Approximation coefficients A4 for the same segments of electrode T8. It can be observed that Log Energy and Normalized Entropies got closer values.

\begin{tabular}{c|c|c|c|} 
Electrode & \multicolumn{3}{c|}{ D4 (Entropy) } \\
T8 & Shannon & Log Energy & Norm \\
\hline $55 \mathrm{~s}$ & $3.8904 \mathrm{e}-09$ & -209.176 & $7.9733 \mathrm{e}-06$ \\
\hline $56 \mathrm{~s}$ & $1.1585 \mathrm{e}-08$ & -201.639 & $1.5977 \mathrm{e}-05$ \\
\hline
\end{tabular}

Table 12 Subject B, left test and entropy values for D4 detail Coefficients

\begin{tabular}{|r|r|r|r|}
\hline \multicolumn{1}{|c|}{$\begin{array}{c}\text { Alectrode } \\
\text { T8 }\end{array}$} & \multicolumn{3}{c|}{ Shannon (Entropy) } \\
\hline $55 \mathrm{~s}$ & $4.9823 \mathrm{e}-05$ & -133.215 & 0.0026 \\
\hline $56 \mathrm{~s}$ & $5.1920 \mathrm{e}-05$ & -132.824 & 0.0027 \\
\hline
\end{tabular}

Table 13 Subject B, left test and entropy values for cA3 approximation Coefficients

\section{Acknowledgments}

We want to thank the UABC for founding this project and to the students that participate in this research: Diana Yara Hernández Abarca, Diana Carolina Ramos Solano, Cecilia del Carmen Solano Mendivil, Rosa Itzel Ortíz Quezada, Ana Cristina Cázarez Meráz. Also, we want to thank the Inter-institutional Program for the Strengthening of Research and the Postgraduate of the Pacific for letting that students of other schools can participate with us.

ESQUEDA-ELIZONDO, José Jaime, TRUJILLO-TOLEDO, Diego Armando, PINTO-RAMOS, Marco Antonio and REYES-MARTÍNEZ, Roberto Alejandro. Methodology for pattern determination in electroencephalographic signals. Journal of Research and Development. 2019 
The following students participated in this project: Diana Saraí Hernández Manzo (IPN), Javier Alejandro Rivera Carreño (IT Los Mochis), Marco Antonio Gástelum León (IT Los Mochis), Gerardo Aldair González Jiménez (IPN), Andrés Aharhel Mercado Velázquez (IPN), Alexis Omar Reyna Soto (IPN).

\section{Conclusions}

We observe that the methodology presented is useful to determine the confidence of the possible pattern. Sometimes, using the entropies and cohere functions directly to the preprocessed signal does not reflect the real significance of the possible pattern.

Working with the entropies of the coefficients of the Discrete Wavelet Transform is useful to validate the possible pattern.

In this case, the Log Energy and the Normalized entropies gave closer values, so they had better performance.

\section{References}

Al-Fahoum, A. S., \& Al-Fraihat, A. A. (2014). Methods of EEG Signal Features Extraction Using Linear Analysis in Frequency and TimeFrequency Domains. ISRN Neuroscience, 2014(September), $1-7$. https://doi.org/10.1155/2014/730218

David, N., Schneider, T. R., Peiker, I., AlJawahiri, R., Engel, A. K., \& Milne, E. (2016). Variability of cortical oscillation patterns: A possible endophenotype in autism spectrum disorders? Neuroscience and Biobehavioral Reviews, 71, 590-600. https://doi.org/10.1016/j.neubiorev.2016.09.031

Djemal, R., Alsharabi, K., Ibrahim, S., \& Alsuwailem, A. (2017). EEG-Based computer aided diagnosis of autism spectrum disorder using wavelet, entropy, and ANN. BioMed Research International, 2017. https://doi.org/10.1155/2017/9816591

Esqueda Elizondo, José Jaime, Chávez Guzmán, Carlos Alberto, Jiménez Beristáin, Laura, Bermúdez Encarnación, E. G. (2018). Análisis de señales electroencefalográficas de personas desarrollando actividades de dibujo. Revista de Tecnología e Innovación, 4(June 2017), 14-23.
Esqueda Elizondo, José Jaime, Rosique Ramírez, Súa Madaí, Pinto Ramos, Marco Antonio, Trujillo Toledo, D. A. (2018). Estimation of the stress levels through electroencephalographic signal analysis of Electronics Engineering students in Permanent Evaluation detected with Burnout risk. Revista Ciencias de La Educación, 2(6), 8-14.

Esqueda Elizondo José Jaime, Hernández Manzo Diana, Bermúdez Encarnación Enrique, Jimenez Beristáin Laura, P. R. M. A. (2016). Manipulación de un brazo robótico mediante señales electroencefalográficas. Revista de Tecnología e Innovación, 3(7), 89-98. Retrieved from

https://ecorfan.org/bolivia/researchjournals/Tec nologia_e_innovacion/vol3num7/Revista_de_T ecnologia_e_Innovación_V3_N7.pdf

Krishnan, S., \& Athavale, Y. (2018). Trends in biomedical signal feature extraction. Biomedical Signal Processing and Control, 43, 41-63. https://doi.org/10.1016/J.BSPC.2018.02.008

Ramadan, R. A., \& Vasilakos, A. V. (2017a). Brain computer interface: control signals review. Neurocomputing, 223(October 2016), 26-44. https://doi.org/10.1016/j.neucom.2016.10.024

Ramadan, R. A., \& Vasilakos, A. V. (2017b). Brain computer interface: control signals review. Neurocomputing, 223(August 2016), 26-44. https://doi.org/10.1016/j.neucom.2016.10.024

Srinivasan, R., Winter, W. R., Ding, J., \& Nunez, P. L. (2007). EEG and MEG coherence: Measures of functional connectivity at distinct spatial scales of neocortical dynamics. Journal of Neuroscience Methods, 166(1), 41-52. https://doi.org/10.1016/j.jneumeth.2007.06.026

W Azlan, W. A., \& Low, Y. F. (2014). Feature extraction of electroencephalogram (EEG) signal - A review. In 2014 IEEE Conference on Biomedical Engineering and Sciences (IECBES) (pp. 801-806). IEEE. https://doi.org/10.1109/IECBES.2014.7047620 